\title{
KONTRIBUSI SEKTOR PERTANIAN PADA PERTUMBUHAN EKONOMI DI PROVINSI
}

\section{JAWA BARAT}

\author{
(Contribution of Agricultural Sector to Economic Growth in West Java Province)
}

\author{
Wiwin Widianingsih \\ Any Suryantini, Irham
}

Jurusan Sosial Ekonomi Pertanian, Fakultas Pertanian,
Universitas Gadjah Mada

\begin{abstract}
This study aims to know the trend of GDRP of agricultural sector in West Java Province, sector and sub-sector of agriculture which has a role as a leading sector in West Java Province and each district in this province, the factors that affect the economic growth of agriculture sector in the West Java Province, and the growth typology of the agricultural sector in West Java Province. The method that used for this study are Trend analysis, Location Quotient (LQ), Dynamic Location Quotient (DLQ), Shift-Share, and Klassen Typology. The results showed that the trend of agriculture sector/sub-sectors' GDRP value were significantly increased and the trend of agriculture sector/sub-sectors' GDRP contribution were significantly decreased over the period year 2003-2012. The agricultural sector is a leading sector for West Java Province and most of its districts. Food crop and the horticultural sub-sector is a leading sector for West Java Province and some districts in this province. The growth of the national economy is the dominant factor affecting the growth of the sector/subsector of agriculture in West Java Province. The competitive advantage (competitiveness) of forestry sub-sector was higher than the same sub-sector in other areas at national level. Food crops and horticultural sub-sector and livestock sub-sector were advanced but depressed sub-sector. Forestry sub-sectors was categorized in developing sub-sector. The agriculture sector, plantation and fisheries sub-sector were categorized in lagging development. Based on $L Q, D L Q$ and Klassen Typology analysis, the results showed that there was a consistent result that were the forestry sub-sector categorized in a leading sub-sector in the future, food crops and horticulture sub-sector categorized in leading sub-sector along year 2003-2012. While sector of agriculture, plantation and fisheries sub-sector categorized in the lagged development sectors.
\end{abstract}

Keywords: GDRP, agriculture, leading commodity, Shift-Share, Klassen Typology.

\section{INTISARI}

Penelitian ini bertujuan untuk mengetahui trend PDRB sektor pertanian di Provinsi Jawa Barat, sektor dan sub sektor pertanian yang berperan sebagai sektor unggulan di Provinsi Jawa Barat dan masing-masing kabupaten/kota di Provinsi Jawa Barat, faktor yang mempengaruhi pertumbuhan ekonomi sektor pertanian di Provinsi Jawa Barat, dan tipologi pertumbuhan sektor pertanian di Provinsi Jawa Barat. Analisis dilakukan menggunakan metode Trend, Location Quotient (LQ), Dynamic Location Quotient (DLQ), Shift-Share, dan Klassen Typology. Hasil penelitian menunjukkan bahwa PDRB sektor/sub sektor pertanian di Provinsi Jawa Barat memiliki kecenderungan meningkat dan kontribusi PDRB sektor/sub sektor pertanian di Provinsi Jawa Barat memiliki kecenderungan menurun yang siginifikan selama periode tahun 2003-2012. Sektor pertanian merupakan sektor non basis bagi Provinsi Jawa Barat dan sebagian besar kabupaten/kota di Provinsi Jawa Barat. Sub sektor tanaman bahan makanan dan hortikultura merupakan sub sektor basis bagi Provinsi Jawa Barat dan sebagian kecil kabupaten/kota di Provinsi Jawa Barat. Pertumbuhan ekonomi nasional merupakan faktor dominan yang berpengaruh terhadap pertumbuhan sektor/sub sektor pertanian di Provinsi Jawa Barat. Sub sektor kehutanan memiliki keunggulan kompetitif (daya saing) yang lebih tinggi dibandingkan sub sektor yang sama di daerah lain di tingkat nasional. Sub sektor tanaman bahan makanan dan hortikultura dan sub sektor peternakan termasuk dalam sub sektor maju tapi tertekan. Sub sektor kehutanan termasuk dalam kategori sub sektor berkembang. Sedangkan sektor pertanian, sub sektor perkebunan dan sub sektor perikanan sebagai sektor/sub sektor yang relatif tertinggal. Hasil analisis dari LQ, DLQ dan Klassen Typology menunjukkan terdapat konsistensi hasil pada sub sektor kehutanan sebagai sub sektor yang dapat diandalkan di masa mendatang, sub sektor tanaman bahan makanan dan hortikultura konsisten sebagai sub sektor yang hanya dapat diandalkan saat ini. Sektor pertanian, sub sektor perkebunan dan perikanan sebagai sektor tertinggal.

Kata kunci : PDRB, pertanian, komoditas unggulan, Shift-Share, Klassen Typology. 


\section{PENDAHULUAN}

Sektor pertanian memiliki kontribusi terhadap pembangunan terutama di daerah, salah satunya di Provinsi Jawa Barat. Pembangunan ekonomi daerah erat kaitannya dengan industrialisasi dan peran sektor pertanian mulai tergantikan oleh sektor industri. Pembangunan ekonomi daerah bertujuan untuk meningkatkan jumlah dan jenis peluang kerja untuk masyarakat daerah. Tolak ukur keberhasilan pembangunan perekonomian daerah dapat dilihat dari pertumbuhan ekonomi dan struktur ekonomi.

Pertumbuhan ekonomi suatu daerah merupakan salah satu unsur utama dalam pembangunan ekonomi regional, meskipun proses pembangunan bukan hanya ditentukan oleh aspek ekonomi saja. Pertumbuhan ekonomi yang cukup tinggi sampai saat ini merupakan target utama pembangunan dalam rencana pembangunan wilayah. Melalui pertumbuhan ekonomi daerah yang cukup tinggi diharapkan kesejahteraan masyarakat dapat ditingkatkan secara bertahap. Kemampuan daerah untuk tumbuh tidak terlepas dari peranan sektor-sektor yang ada dalam suatu perekonomian.

Pertumbuhan dan peningkatan PDRB dari tahun ke tahun merupakan indikator dari keberhasilan pembangunan daerah. Sektor- sektor ekonomi yang membentuk PDRB dikategorikan menjadi sembilan sektor usaha yaitu: (1) Pertanian, (2) Pertambangan dan penggalian, (3) Industri pengolahan, (4) Listrik, gas dan air bersih, (5) Bangunan, (6) Perdagangan, hotel dan restoran, (7) Pengangkutan dan komunikasi,
(8) Keuangan, persewaan dan jasa perusahaan, dan (9) Sektor jasa lainnya. Sinergi antar sektor ekonomi sangat penting dalam membentuk struktur ekonomi yang kuat. Sinergi antara sektor pertanian, industri dan jasa yang kuat akan membentuk perekonomian yang efisien, dan hal ini akan turut mendorong pertumbuhan ekonomi daerah (Sjafrizal, 2008). Semakin besar sumbangan yang diberikan oleh masing-masing sektor ekonomi terhadap PDRB suatu daerah maka pertumbuhan ekonomi akan berjalan ke arah yang lebih baik.

Nilai dan kontribusi PDRB Provinsi Jawa Barat pada tahun 2010-2012 dapat dilihat pada tabel 1.1.

Sektor industri pengolahan adalah sektor ekonomi penyumbang PDRB terbesar di Provinsi Jawa Barat dengan kontribusi sebesar 42,08\% pada tahun 2010. Kontribusi sektor ini semakin menurun sampai tahun 2012 menjadi 41,07\%. Kontribusi sektor pertanian pada tahun 2010 yaitu sebesar $13,08 \%$ dan terus menurun sampai 11,47 pada tahun 2012. Masuknya sektor pertanian ke dalam tiga besar penopang PDRB di Provinsi Jawa Barat menunjukkan bahwa sektor pertanian merupakan sektor yang penting dalam pertumbuhan ekonomi daerah (Badan Pusat Statistik, 2012).

Pembangunan di Provinsi Jawa Barat tercantum dalam Peraturan Daerah No.9 Tahun 2008 yang menyatakan tentang Rencana Pembangunan Jangka Panjang Daerah Provinsi (RPJPD) Jawa Barat tahun 2005-2025. Sektor pertanian menjadi salah satu di antara tujuh bidang unggulan sebagai

Tabel 1.1. Nilai dan Kontribusi PDRB Atas Dasar Harga Konstan 2000 Provinsi Jawa Barat Tahun

\begin{tabular}{lrrrrrr}
\hline \multirow{2}{*}{\multicolumn{1}{c}{ Sektor }} & \multicolumn{2}{c}{2010} & \multicolumn{2}{c}{2011} & \multicolumn{2}{c}{2012} \\
\cline { 2 - 7 } & \multicolumn{1}{c}{ Rp. } & \multicolumn{1}{c}{$\%$} & \multicolumn{1}{c}{ Rp. } & \multicolumn{1}{c}{ Rp. } & \multicolumn{1}{c}{5} \\
\hline Pertanian & 42.137 & 13,08 & 42.101 & 12,27 & 41.802 & 11,47 \\
Pertambangan dan penggalian & 7.465 & 2,32 & 7.085 & 2,06 & 6.576 & 1,80 \\
Industri pengolahan & 135.595 & 42,08 & 144.010 & 41,97 & 149.677 & 41,07 \\
Listrik, gas dan air & 7.316 & 2,27 & 7.426 & 2,16 & 8.009 & 2,20 \\
Konstruksi & 11.810 & 3,67 & 13.483 & 3,93 & 15.318 & 4,20 \\
Perdagangan, hotel dan restoran & 70.083 & 21,75 & 75.770 & 22,08 & 84.524 & 23,20 \\
Pengangkutan dan komunikasi & 15.353 & 4,76 & 17.645 & 5,14 & 19.763 & 5,42 \\
Keuangan, sewa dan jasa perusahaan & 10.565 & 3,28 & 11.985 & 3,49 & 13.210 & 3,63 \\
Jasa-jasa & 21.900 & 6,80 & 23.606 & 6,88 & 25.527 & 7,01 \\
\hline Total PDRB & 322.224 & 100 & 343.111 & 100 & 364.406 & 100 \\
\hline
\end{tabular}

Sumber : Badan Pusat Statistik, 2012. Diolah. 
penciri pembangunan Jawa Barat termaju di Indonesia pada tahun 2025 dengan misi pengelolaan pertanian dan kelautan yang lebih intensif. Rencana Pembangunan Jangka Menengah Daerah (RPJMD) tahun 2013-2018 direncanakan sebagai tahap pemantapan pembangunan secara menyeluruh. Pembangunan di sektor pertanian diharapkan dapat memperkuat pembangunan ekonomi pedesaan dan ekonomi regional. Rencana pengembangan Metropolitan Bodebek-Karpur, Metropolitan Bandung Raya, dan Metropolitan Cirebon Raya dalam rangka penguatan ekonomi regional memacu pertumbuhan ekonomi di Jawa Barat semakin maju di tahun 2025. Pembangunan ekonomi yang pesat diharapkan dapat mengurangi ketimpangan ekonomi serta berdampak pada kesejahteraan masyarakat di Provinsi Jawa Barat (Bapedda Prov. Jawa Barat, 2013).

Misi kedua dalam RPJPD Provinsi Jawa Barat tahun 2005-2025 yaitu meningkatkan perekonomian yang berdaya saing dan berbasis potensi daerah diperlukan adanya keterkaitan antara sektor primer, sekunder dan tersier dalam suatu sistem yang produktif untuk meningkatkan keterkaitan pembangunan ekonomi antar wilayah. Pembangunan ekonomi daerah Jawa Barat tahun 2005-2025 diarahkan kepada peningkatan nilai tambah segenap sumber daya ekonomi, salah satunya melalui pengembangan pertanian (Pemerintah Prov. Jawa Barat, 2013).

Berdasarkan RPJMD Provinsi Jawa Barat tahun 2013-2018, sektor pertanian dijadikan salah satu jalan untuk mencapai keberhasilan pembangunan daerah di Provinsi Jawa Barat. Upaya yang dilakukan dalam pencapaian misi kedua RPJPD Provinsi Jawa Barat tahun 2005-2025 yang berbasis potensi daerah diperlukan analisis terkait kontribusi dan potensi sektor pertanian dalam perekonomian di Provinsi Jawa Barat. Hal tersebut bertujuan untuk mengetahui keberhasilan pembangunan ekonomi daerah di Provinsi Jawa Barat.

Penelitian ini bertujuan untuk mengetahui trend pertumbuhan PDRB sektor pertanian di Provinsi Jawa Barat, menentukan sektor dan sub sektor pertanian yang berperan sebagai sektor unggulan di Provinsi Jawa Barat, mengetahui faktor yang mempengaruhi pertumbuhan ekonomi sektor pertanian di Provinsi Jawa Barat, dan mengetahui tipologi pertumbuhan sektor pertanian di Provinsi Jawa Barat.

\section{METODE PENELITIAN}

Metode dasar yang digunakan adalah metode deskriptif analitis, yaitu metode penelitian yang dilakukan untuk meneliti suatu objek, suatu set kondisi, suatu sistem pemikiran, atau suatu kelas peristiwa pada masa sekarang. Tujuan dari analisis ini adalah untuk membuat deskripsi atau gambaran secara sistematis, factual dan akurat mengenai fakta-fakta, sifat-sifat serta hubungan antar fenomena yang diselidiki (Nazir, 2011). Data yang digunakan dalam penelitian ini adalah data sekunder. Sumber data yang digunakan dalam penelitian ini diperoleh dari Badan Pusat Statistik Provinsi Jawa Barat.

\section{Analisis Pertumbuhan PDRB Sektor Pertanian}

Analisis trend dapat digunakan untuk mengetahui perubahan nilai suatu variabel dari waktu ke waktu. Untuk mengetahui kecenderungan pertumbuhan PDRB sektor pertanian di Provinsi Jawa Barat selama periode tahun pengamatan, maka formulasi persamaan analisis trend adalah sebagai berikut:

$$
\mathrm{Y}=\mathrm{a}+\mathrm{bX}
$$

keterangan :

$\mathrm{Y}=$ nilai $\mathrm{PDRB}$ sektor pertanian

Provinsi Jawa Barat

a = nilai trend

$\mathrm{b}=$ penambahan nilai trend, dan

$\mathrm{X}=$ tahun

Pengujian model dilakukan dengan Uji $\mathrm{R}^{2}$ (koefisien determinasi) dan Uji t. Menurut Gujarati (2006), Uji $R^{2}$ dilakukan untuk mengetahui ketepatan model dan Uji t digunakan untuk menguji pengaruh variabel bebas (waktu) terhadap variabel tak bebas (PDRB sektor pertanian Provinsi Jawa Barat). Nilai $\mathrm{R}^{2}$ menyatakan proporsi variasi dalam variabel tak bebas yang dijelaskan oleh variabel yang menjelaskan. Bila nilai $\mathrm{R}^{2}$ semakin mendekati 1 , maka garis regresi semakin baik. Rumus Uji $\mathrm{R}^{2}$ adalah sebagai berikut:

$$
R^{2}=\frac{\sum(\hat{\mathrm{Y}}-\overline{\mathrm{Y}})^{2}}{\sum\left(\mathrm{Y}_{\mathrm{i}}-\overline{\mathrm{Y}}\right)^{2}}=\frac{E S S}{T S S}
$$

Perumusan hipotesis 1 :

H0 : koefisien regresi tidak signifikan $(\beta 0=0)$

H1 : koefisien regresi signifikan $(\beta 1 \neq 0)$ 


$$
t_{\text {hitung }}=\frac{\beta_{1}}{\operatorname{se} \beta_{1}}
$$

Keterangan :

$\beta 1=$ koefisien regresi

Se $\beta 1=$ standart error koefisien regresi

$\mathrm{t}$ tabel $=\mathrm{t}(\alpha / 2 ; n-\mathrm{k}), \mathrm{n}$ adalah jumlah sampel dan $\mathrm{k}$ adalah jumlah variabel

Kriteria :

jika nilai t sig $<\alpha$, maka $\mathrm{H} 0$ ditolak

jika nilai $\mathrm{t}$ sig $>\alpha$, maka $\mathrm{H} 0$ diterima

\section{Analisis Sektor/Sub Sektor Unggulan}

Identifikasi sektor/sub sektor unggulan di suatu wilayah dapat menggunakan analisis Location Quotient dan Dynamic Location Quotient.

\subsection{Analisis Location Quotient (LQ)}

Location Quotient (LQ) merupakan suatu pendekatan yang digunakan untuk mengukur kinerja basis ekonomi suatu daerah, artinya digunakan untuk pengujian sektor-sektor ekonomi yang termasuk dalam kategori sektor unggulan. LQ dihitung dengan mengukur konsentrasi dari suatu kegiatan sektor ekonomi dalam suatu daerah dibandingkan dengan peranannya dalam perekonomian daerah tersebut dengan peran kegiatan sektor ekonomi sejenis dalam perekonomian regional atau nasional (Arsyad, 2010).

$$
L Q=\frac{y i / y j}{Y i / Y j}
$$

Keterangan:

yi = PDRB sektor/sub sektor pertanian di kabupaten/kota j

$\mathrm{yj}=$ PDRB total kabupaten $/$ kota $\mathrm{j}$

$\mathrm{Yi}=\mathrm{PDRB}$ sektor/sub sektor pertanian di provinsi $\mathrm{Yj}=\mathrm{PDRB}$ total di provinsi

\section{Kriteria :}

a. LQ $>1$, berarti sektor/sub sektor pertanian di daerah tersebut merupakan sektor basis. b. LQ $<1$, berarti sektor/sub sektor pertanian di daerah tersebut merupakan sektor non basis.

c. $\quad \mathrm{LQ}=1$, berarti produk domestik yang dimiliki daerah tersebut habis dikonsumsi oleh daerah tersebut (swasembada).

\subsection{Analisis Dynamic Location Quotient(DLQ)}

Dynamic Location Quotient (DLQ) adalah modifikasi dari LQ dengan mengakomodasi faktor laju pertumbuhan keluaran sektor ekonomi dari waktu ke waktu. Nilai DLQ dihitung menggunakan rumus sebagai berikut (Nugroho, 2010) :

$$
D L Q=\left[\frac{\left(1+g_{i j}\right) /\left(1+g_{i}\right)}{\left(1+G_{i}\right) /(1+G)}\right]^{t}
$$

keterangan :

gij = rerata laju pertumbuhan PDRB sektor/sub sektor pertanian di kabupaten/kota $\mathrm{j}$

$\mathrm{gj}$ = rerata laju pertumbuhan PDRB kabupaten/ kota $\mathrm{j}$

$\mathrm{Gi}=$ rerata laju pertumbuhan sektor/sub sektor pertanian di provinsi

$\mathrm{G}=$ rerata laju pertumbuhan PDRB total provinsi

$\mathrm{t}=$ tahun penelitian

Kriteria :

a. DLQ $>1$, berarti potensi perkembangan sektor/ sub sektor pertanian di daerah lebih cepat dibandingkan sektor yang sama di daerah referensi.

b. DLQ $<1$, berarti potensi perkembangan sektor/ sub sektor pertanian di daerah lebih lambat dibandingkan sektor yang sama di daerah referensi.

c. $\mathrm{DLQ}=1$, berarti potensi perkembangan sektor/ sub sektor pertanian di daerah sama dengan sektor yang sama di daerah referensi.

Tabel 1.2. Klasifikasi Sektor/Sub Sektor berdasarkan Gabungan nilai LQ dan DLQ

\begin{tabular}{ccc}
\hline Nilai & LQ $>1$ & LQ $<1$ \\
\hline DLQ $>1$ & Unggulan & Andalan \\
DLQ $<1$ & Prospektif & Tertinggal \\
\hline
\end{tabular}

Sumber: Kuncoro, 2012 
Gabungan antara nilai LQ dan DLQ dijadikan kriteria dalam menentukan apakah sektor ekonomi tersebut tergolong unggulan, prospektif, andalan, dan kurang prospektif (Kuncoro, 2012).

\section{Analisis Struktur dan Laju Pertumbuhan}

Analisis Shift Share digunakan untuk menganalisis perubahan struktur ekonomi di suatu daerah terhadap struktur ekonomi wilayah yang lebih tinggi sebagai pembanding (provinsi/ nasional). Komponen analisis Shift Share terdiri dari pertumbuhan ekonomi referensi provinsi atau nasional (national growth effect), pergeseran proporsional (proportional shift) dan pergeseran diferensial (differential shift). Formulasi analisis Shift Share menurut Widodo (2006) adalah sebagai berikut :

$$
\begin{aligned}
D_{i j} & =N_{i j}+M_{i j}+C_{i j} \\
N_{i j} & =E i j x \text { rn } \\
M_{i j} & =E i j(r i n-r n) \\
C_{i j} & =E i j(r i j-r i n) \\
r n & =\left(E^{*} n-E n\right) / E n \\
r i n & =\left(E^{*} i n-E i n\right) / E i n \\
r i j & =\left(E^{*} i j-E i j\right) / E i j
\end{aligned}
$$

Keterangan :

Dij = dampak riil pertumbuhan ekonomi daerah

$\mathrm{Nij}=$ pengaruh pertumbuhan ekonomi referensi

Mij = pengaruh pergeseran proporsional (Proportional Shift) atau bauran industri (Mixed Shift)

Cij = pengaruh keunggulan kompetitif (Differential Shift/Competitive Shift)

Eij = PDRB sektor i di provinsi pada tahun awal $\mathrm{E}^{*} \mathrm{ij}=\mathrm{PDRB}$ sektor i di provinsi pada tahun akhir Ein $=$ PDRB sektor i nasional pada tahun awal
$\mathrm{E}^{*}$ in $=$ PDRB sektor i nasional pada tahun akhir

En $=$ total PDRB nasional pada tahun awal

$\mathrm{E}^{*} \mathrm{n}=$ total PDRB nasional pada tahun awal

rn = laju pertumbuhan total PDRB nasional

rin = laju pertumbuhan PDRB sektor i nasional

rij = laju pertumbuhan PDRB sektor i provinsi

\section{Analisis Tipologi Pertumbuhan Sektor Pertanian}

Berdasarkan Matrix Klassen, suatu sektor ekonomi dapat diklasifikasikakn menjadi sektor maju, maju tapi tertekan, berkembang, dan relatif tertinggal. Analisis ini mendasarkan pengelompokan suatu sektor pada pertumbuhan dan kontribusi sektor terhadap total PDRB daerah (Widodo, 2006) :

$$
\begin{aligned}
\mathrm{rj} & =[(\mathrm{Vjt}-\mathrm{Vjo}) / \mathrm{Vjo}] \times 100 \% \\
\mathrm{rn} & =[(\mathrm{Vnt}-\mathrm{Vno}) / \mathrm{Vno}] \times 100 \% \\
\mathrm{yj} & =\mathrm{Vj} / \mathrm{Yj} \\
\mathrm{yn} & =\mathrm{Vn} / \mathrm{Yn}
\end{aligned}
$$

\section{Keterangan :}

rj = laju pertumbuhan PDRB sektor/sub sektor pertanian kabupaten/kota

$\mathrm{rn} \quad=$ laju pertumbuhan PDRB sektor/sub sektor pertanian provinsi

yj $\quad=$ kontribusi PDRB sektor/sub sektor pertanian terhadap total PDRB kabupaten/kota

yn $=$ kontribusi sektor/sub sektor pertanian

\begin{tabular}{|c|c|c|}
\hline \multirow{2}{*}{$\begin{array}{l}\text { Laju Pertumbuhan } \\
\text { Sektoral (r) }\end{array}$} & \multicolumn{2}{|c|}{ Kontribusi Sektoral (y) } \\
\hline & yj $>$ yn & yj $<$ yn \\
\hline \multirow[t]{2}{*}{$\mathrm{rj}>\mathrm{rn}$} & Sektor Maju & Sektor Berkembang \\
\hline & (Tipe Satu) & (Tipe Tiga) \\
\hline \multirow[t]{2}{*}{$\mathrm{rj}<\mathrm{rn}$} & Sektor Maju tapi Tertekan & Sektor Relatif Tertinggal \\
\hline & (Tipe Dua) & (Tipe Empat) \\
\hline
\end{tabular}
terhadap total PDRB provinsi

Vjo = PDRB sektor/sub sektor pertanian kabupaten/kota pada tahun awal

Vjt $=$ PDRB sektor/sub sektor pertanian kabupaten/kota pada tahun akhir

Vno $=$ PDRB sektor pertanian provinsi pada tahun awal

Vnt $=$ PDRB sektor pertanian provinsi pada tahun akhir

Tabel 1.3. Matriks Tipologi Klassen

Sumber : Widodo, 2006 
$\mathrm{Vj} \quad=$ PDRB sektor pertanian kabupaten/kota

$\mathrm{Vn}=$ PDRB sektor pertanian provinsi

$\mathrm{Yj}=$ PDRB total kabupaten/kota

Yn $=$ PDRB total provinsi

\section{HASIL DAN PEMBAHASAN}

\section{Pertumbuhan PDRB Sektor/Sub Sektor Pertanian}

Pertumbuhan ekonomi daerah merupakan perubahan perekonomian suatu daerah untuk menjadi lebih baik dan mencerminkan kesejahteraan masyarakatnya. Pertumbuhan ekonomi suatu daerah menjadi indikator keberhasilan pembangunan ekonomi di daerah. Pertumbuhan ekonomi dapat dilihat dengan adanya kenaikan nilai tambah pada sektor-sektor ekonomi. Laju pertumbuhan PDRB sektoral juga dapat digunakan sebagai dasar pembuatan proyeksi atau perkiraan penerimaan suatu daerah untuk perencanaan pembangunan daerah atau sektoral regional.

Selama kurun waktu analisis, dapat dilihat kecenderungan (trend) pertumbuhan sektor/sub sektor pertanian di Provinsi Jawa Barat berdasarkan nominal PDRB dan kontribusi PDRB.

1. PDRB Sektor Pertanian

Pendapatan Domestik Regional Bruto (PDRB) sektor pertanian di Provinsi Jawa Barat terus bertambah dan memiliki kecenderungan meningkat selama tahun 2003-2012. Kinerja sektor pertanian dalam menghasilkan nilai tambah dinilai baik karena selalu mengalami peningkatan dari tahun ke tahun.

Nilai tambah sektor pertanian mengalami peningkatan setiap tahunnya. Potensi sumber daya alam yang terdapat di Provinsi Jawa Barat yang dimanfaatkan dengan optimal merupakan salah satu pendorong pertumbuhan ekonomi suatu daerah. Berdasarkan teori ekonomi Keynes dalam model interregional income, pendapatan yang diterima suatu daerah dipengaruhi oleh konsumsi masyarakat, investasi, pengeluaran pemerintah, selisih antara nilai ekspor dan impor. Untuk mengetahui pengaruh waktu terhadap pertumbuhan nominal PDRB sektor pertanian di Provinsi Jawa Barat maka dilakukan uji statistik yang hasilnya dapat dilihat pada tabel 5.1.

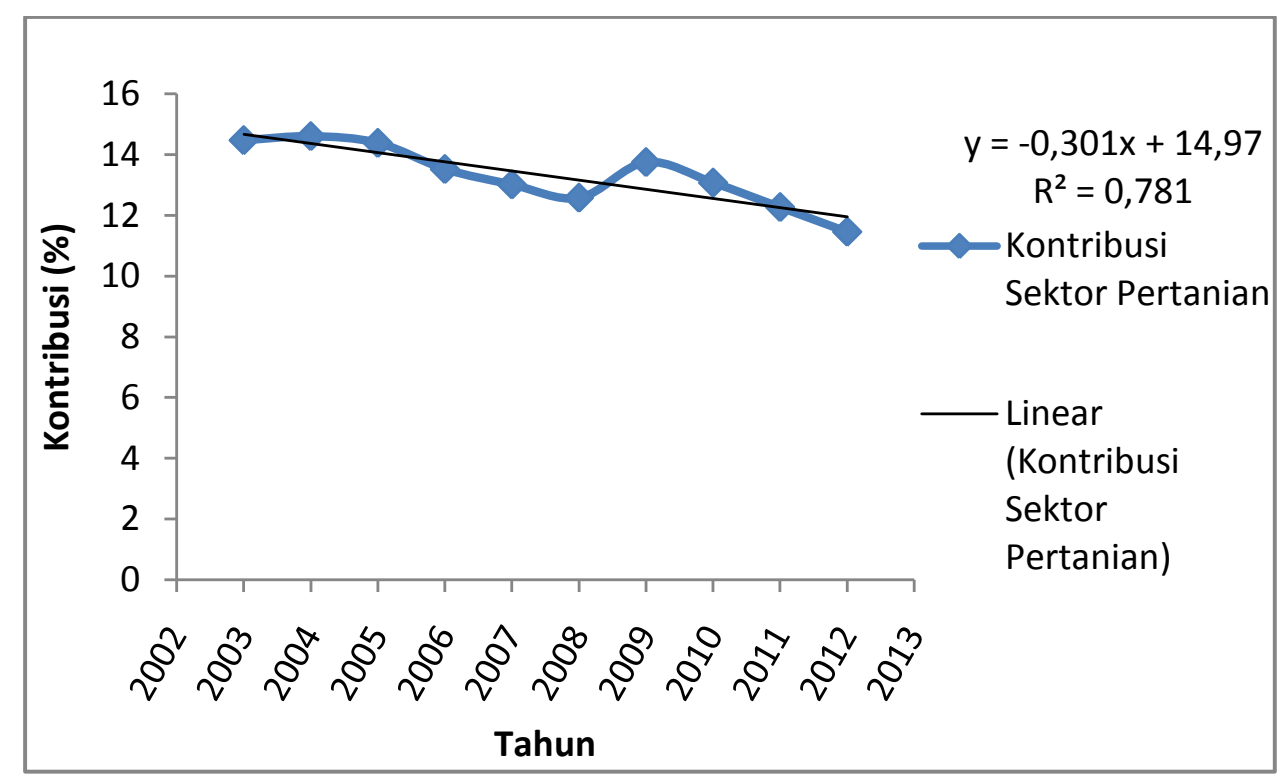

Gambar 1.1. Trend PDRB Sektor Pertanian Provinsi Jawa Barat Tahun 2003-2012

Sumber: Analisis Data Sekunder, 2014 
Tabel 1.4. Hasil Uji t Trend Linear PDRB Sektor

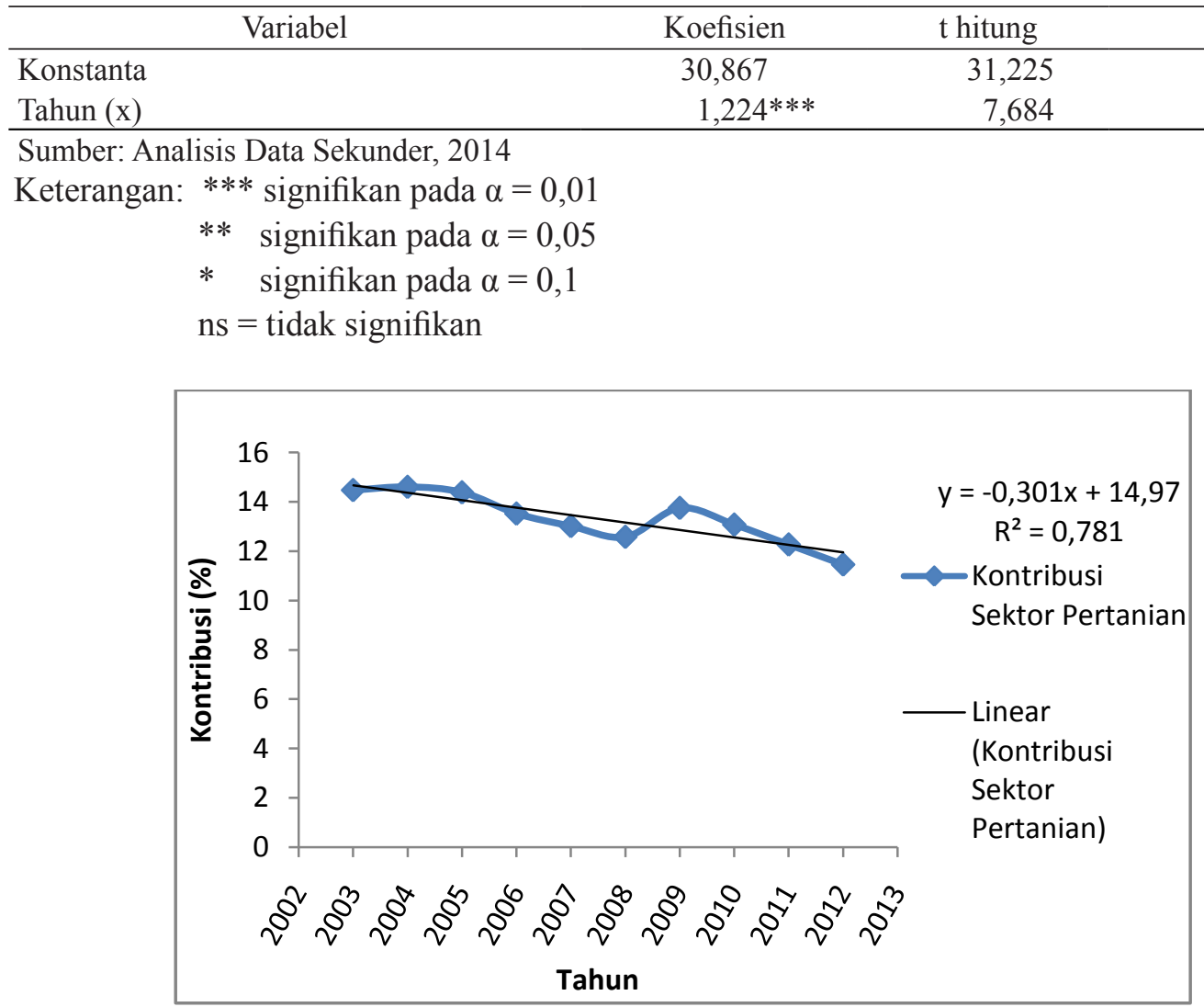

Gambar 1.2. Trend Kontribusi PDRB Sektor Pertanian Provinsi Jawa Barat Tahun 2003-2012

Sumber: Analisis Data Sekunder, 2014.

Berdasarkan hasil uji statistik, analisis trend PDRB sektor pertanian di Provinsi Jawa Barat menghasilkan signifikansi t 0,000 dengan koefisien 1,224 . Hal ini menunjukkan bahwa variabel waktu (tahun) berpengaruh secara signifikan terhadap PDRB sektor pertanian. Model trend linier tepat untuk menggambarkan kecenderungan PDRB sektor pertanian selama kurun waktu 10 tahun (2003-2012), PDRB sektor pertanian di Provinsi Jawa Barat cenderung mengalami peningkatan sebesar 1,224 setiap tahun.

Pembangunan ekonomi suatu daerah erat kaitannya dengan industrialisasi. Sektor industri berkembang lebih cepat sehingga menggeser posisi sektor pertanian. Kontribusi sektor industri di daerah menjadi lebih besar dibandingkan dengan kontribusi sektor pertanian. Kontribusi sektor pertanian dihitung berdasarkan besar nilai tambah pada sektor pertanian terhadap nilai tambah total sektor. Grafik kecenderungan kontribusi sektor pertanian di Provinsi Jawa Barat dapat dilihat pada gambar 5.2 .
Kontribusi sektor pertanian terhadap PDRB Provinsi Jawa Barat tidak mengalami fluktuasi yang begitu mencolok. Hal ini terlihat dari kecenderungan kontribusi sektor pertanian yang menurun sepanjang tahun 2003-2012. Strategi pembangunan ekonomi di daerah yang mengadopsi pembangunan di negara-negara maju yaitu meningkatkan pertumbuhan nominal PDRB sektor pertanian dan menurunkan kontribusi sektor pertanian terhadap PDRB. Strategi pemerintah daerah Jawa Barat dalam pembangunan sudah diarahkan pada pembangunan di daerah maju karena upaya meningkatkan nominal PDRB sektor pertanian setiap tahun dan menurunkan kontribusi PDRB sektor pertanian setiap tahun. Hal ini juga tercermin pada semua subsektor pertanian, yaitu PDRB dengan kecenderungan meningkat dan kontribusi PDRB dengan kecenderungan menurun. Keadaan ini kemudian diarahkan pada majunya sektor industri pengolahan sehingga tenaga kerja off farm akan banyak terserap di sektor tersebut. Berdasarkan data tahun 2012, proporsi kontribusi 
Tabel 1.5. Hasil Uji t Trend Linear PDRB Sektor

\begin{tabular}{|c|c|c|c|}
\hline Variabel & Koefisien & t hitung & $\alpha$ \\
\hline Konstanta & 14,972 & 42,794 & 0,000 \\
\hline Tahun (x) & $-0,302 * * *$ & $-5,348$ & 0,001 \\
\hline
\end{tabular}

Sumber: Analisis Data Sekunder, 2014

Keterangan: $* * *$ signifikan pada $\alpha=0,01$

** signifikan pada $\alpha=0,05$

* $\quad$ signifikan pada $\alpha=0,1$

$\mathrm{ns}=$ tidak signifikan

Tabel 1.6. Nilai LQ Sektor/Sub Sektor Pertanian Provinsi Jawa Barat

\begin{tabular}{ccccccc}
\hline \multirow{2}{*}{ Tahun } & \multicolumn{7}{c}{ LQ Sektor/Sub Sektor } \\
\cline { 2 - 7 } & 1 & 2 & 3 & 4 & 5 & 6 \\
\hline 2003 & 0,950 & $1,415^{*}$ & 0,339 & $1,043^{*}$ & 0,111 & 0,365 \\
2004 & 0,979 & $1,441^{*}$ & 0,357 & $1,149^{*}$ & 0,141 & 0,344 \\
2005 & 0,992 & $1,460^{*}$ & 0,344 & $1,175^{*}$ & 0,192 & 0,339 \\
2006 & 0,952 & $1,400^{*}$ & 0,335 & $1,161^{*}$ & 0,208 & 0,298 \\
2007 & 0,942 & $1,405^{*}$ & 0,315 & $1,121^{*}$ & 0,195 & 0,282 \\
2008 & 0,921 & $1,358^{*}$ & 0,334 & $1,079^{*}$ & 0,185 & 0,281 \\
2009 & $1,013^{*}$ & $1,523^{*}$ & 0,356 & $1,070^{*}$ & 0,153 & 0,306 \\
2010 & 0,993 & $1,515^{*}$ & 0,330 & $1,044^{*}$ & 0,157 & 0,297 \\
2011 & 0,960 & $1,480^{*}$ & 0,329 & 0,993 & 0,151 & 0,290 \\
2012 & 0,916 & $1,410^{*}$ & 0,327 & 0,959 & 0,148 & 0,286 \\
\hline
\end{tabular}

Sumber: Analisis Data Sekunder, 2014.

Keterangan : $\quad 1=$ sektor pertanian

$2=$ sub sektor tanaman bahan makanan dan hortikultura

$3=$ sub sektor perkebunan

$4=$ sub sektor peternakan

$5=$ sub sektor kehutanan

$6=$ sub sektor perikanan

$*=$ sektor/sub sektor basis

sektor pertanian terhadap perekonomian Provinsi Jawa Barat adalah sebesar 11,47\% dan menduduki peringkat ketiga besar. Sektor ekonomi yang kontribusinya mendominasi perekonomian Provinsi Jawa Barat berasal dari sektor industri pengolahan $(41,07 \%)$ dan sektor perdagangan, hotel dan restoran $(23,20 \%)$. Untuk melihat pengaruh waktu terhadap kontribusi PDRB sektor pertanian maka dilakukan uji statistik yang hasilnya dapat dilihat pada tabel 5.2.

Berdasarkan hasil analisis regresi pada tabel 5.2, variabel waktu signifikan terhadap variabel kontribusi sektor pertanian terhadap PDRB Provinsi Jawa Barat. Kontribusi sektor pertanian terhadap PDRB mengikuti pola trend linier. Nilai koefisien regresi variabel waktu adalah sebesar $-0,302$. Hal ini menandakan bahwa setiap tahun kontribusi sektor pertanian menurun sebesar $0,302 \%$ pada periode 2003-2012. Penurunan kontribusi sektor pertanian menunjukkan bahwa laju pertumbuhan sektor pertanian di Provinsi Jawa Barat lebih lambat dibandingkan dengan laju pertumbuhan ekonomi lainnya yang lebih cepat (tabel 4.6).

\section{Klasifikasi Sektor/Sub Sektor Pertanian Basis dan Non Basis}

Pembangunan sektor pertanian sebagai program prioritas dalam Rencana Pembangunan Jangka Menengah Daerah (RPJMD) tahun 20132018 dan Rencana Pembangunan Jangka Panjang Daerah (RPJPD) tahun 2005-2025 diharapkan dapat memberikan nilai tambah yang besar sehingga mendukung pertumbuhan ekonomi Provinsi Jawa Barat untuk terus meningkat. Pengembangan sektor pertanian akan lebih cepat jika dilakukan dengan lebih spesifik yaitu melalui analisis untuk 
mengetahui sub sektor basis atau non basis. Hasil klasifikasi sektor/sub sektor pertanian sebagai sektor basis atau non basis dapat dijadikan acuan oleh pemerintah dalam melaksanakan program prioritas pembangunan daerah.

\section{a. Analisis Location Quotient (LQ)}

Peran suatu sektor ekonomi dapat dianalisis menggunakan analisis Location Quotient (LQ), yaitu metode untuk menentukan sektor-sektor ekonomi dalam PDRB yang digolongkan ke dalam sektor basis dan non basis di suatu wilayah. LQ menggambarkan perbandingan kontribusi suatu sektor/sub sektor di daerah (provinsi) terhadap sektor ekonomi yang sama pada tingkat perekonomian di atasnya (nasional). Apabila nilai LQ > 1 maka sektor ekonomi tersebut merupakan sektor basis di provinsi dan peranan sektor/sub sektor tersebut di provinsi lebih dominan daripada peranannya di tingkat nasional. Apabila nilai LQ $<1$ maka sektor ekonomi tersebut merupakan sektor non basis di provinsi dan peranan sektor/ sub sektor tersebut di provinsi lebih kecil daripada peranannya di tingkat nasional. Nilai LQ dapat digunakan oleh pemerintah Provinsi Jawa Barat sebagai petunjuk untuk dijadikan dasar dalam menentukan sektor yang potensial dikembangkan. Sektor yang berperan sebagai sektor basis maka sektor tersebut tidak hanya dapat memenuhi kebutuhan di dalam daerah tetapi juga mampu memebuhi kebutuhan daerah lain karena surplus dari produk sektor tertentu, serta menjadi sektor prioritas sebagai penggerak perekonomian dalam pembangunan daerah.

Sektor pertanian terdiri dari lima sub sektor, yaitu sub sektor tanaman bahan makanan dan hortikultura, sub sektor perkebunan, sub sektor peternakan, sub sektor kehutanan, dan sub sektor perikanan. Hasil analisis LQ untuk sektor/sub sektor pertanian selama tahun 2003-2012 dapat dilihat pada tabel 5.13. Hasil analisis menunjukkan bahwa sektor pertanian di tingkat Provinsi Jawa Barat memiliki nilai LQ 0,916 pada tahun 2012. Hal tersebut berarti sektor pertanian merupakan sektor non basis untuk Provinsi Jawa Barat. Selama kurun waktu tahun 2003-2012, sektor pertanian cenderung mengalami penurunan nilai LQ dan hanya pada tahun 2009 berperan sebagai sektor basis. Kontribusi sektor pertanian terhadap PDRB Provinsi Jawa Barat lebih rendah apabila dibandingkan kontribusi sektor pertanian terhadap PDB nasional. Sektor pertanian Provinsi Jawa Barat juga belum mampu memenuhi kebutuhal lokal di regionnya sehingga kegiatan ekspor ke daerah lain tidak dapat dilakukan. Peran sektor pertanian sebagai sektor non basis merupakan akumulasi dari peran 4 sub sektor pertanian sebagai sub sektor non basis.

Berdasarkan nilai LQ sub sektor pertanian tahun 2003-2012 menunjukkan bahwa sub sektor tanaman bahan makanan dan hortikulutura merupakan sub sektor pertanian yang basis, sedangkan keempat sub sektor lainnya berperan sebaagai sub sektor non basis di Provinsi Jawa Barat. Hal ini berarti bahwa kontribusi sub sektor tanaman bahan makanan dan hortikultura dalam PDRB Provinsi Jawa Barat lebih besar dibandingkan kontribusi sub sektor yang sama dalam PDB nasional. Sub sektor tanaman bahan makanan dan hortikultura telah dapat memenuhi kebutuhan daerahnya (lokal) dan mampu mengekspor ke daerah lain selama periode 2003-2012 karena terdapat surplus produksi dari sub sektor tersebut. Dari kegiatan ekspor produk ke daerah lain, maka pendapatan di Provinsi Jawa Barat akan bertambah. Peningkatan pendapatan di provinsi juga akan meningkatkan permintaan pada produk dari sektor non basis, sehingga kenaikan permintaan ini akan mendorong kenaikan investasi pada sub sektor non basis. Oleh karena itu, sub sektor tanaman bahan makanan dan hortikultura perlu dikembangkan di Provinsi Jawa Barat.

Sub sektor yang berperan sebagai sub sektor non basis menunjukkan apabila kontribusi sub sektor tersebut di provinsi lebih kecil daripada kontribusinya di tingkat nasional. Awalnya sub sektor peternakan merupakan sub sektor basis di Provinsi Jawa Barat, namun kecenderungan nilai LQ mengalami penurunan sehingga pada tahun 2011 dan 2012 sub sektor peternakan menjadi sub sektor non basis. Keempat sub sektor tersebut hanya mampu memenuhi kebutuhan dari produk sub sektor non basis dalam lingkup lokal dan memerlukan impor dari daerah lain untuk memenuhi kebutuhannya.

\section{b. Analisis Dynamic Location Quotient (DLQ)}

Kelemahan analisis LQ adalah hasilnya yang bersifat statis. Analisis Dynamic Location Quotient (DLQ) dilakukan untuk melengkapi analisis LQ 
Tabel 1.7. Nilai DLQ Sektor/Sub Sektor

\begin{tabular}{lc}
\hline \multicolumn{1}{c}{ Sektor/Sub Sektor } & DLQ \\
\hline Pertanian & 0,965 \\
Tanaman Bahan Makanan dan Hortikultura & 0,997 \\
Perkebunan & 0,964 \\
Peternakan & 0,920 \\
Kehutanan & $1,342 *$ \\
Perikanan & 0,783 \\
\hline
\end{tabular}

Sumber: Analisis Data Sekunder, 2014.

Keterangan : $*=$ berpotensi menjadi sektor/sub sektor basis di masa mendatang

Tabel 1.8. Klasifikasi Sektor/Sub Sektor Pertanian Provinsi Jawa Barat

\begin{tabular}{|c|c|c|c|}
\hline Sektor/Sub Sektor & LQ & DLQ & Keterangan \\
\hline Pertanian & 0,916 & 0,965 & Tertinggal \\
\hline Tanaman Bahan Makanan \& Hortikultura & 1,410 & 0,997 & Prospektif \\
\hline Perkebunan & 0,327 & 0,964 & Tertinggal \\
\hline Peternakan & 0,959 & 0,920 & Tertinggal \\
\hline Kehutanan & 0,148 & 1,342 & Andalan \\
\hline Perikanan & 0,286 & 0,783 & Tertinggal \\
\hline
\end{tabular}

Sumber: Analisis Data Sekunder, 2014.

Sumber: Analisis Data Sekunder, 2014.

Keterangan : $*=$ berpotensi menjadi sektor/sub sektor basis di masa mendatang

karena analisis LQ tidak dapat digunakan untuk memprediksi basis atau non basisnya suatu sektor pada masa yang akan datang. DLQ menggambarkan perbandingan laju pertumbuhan sektor/sub sektor pertanian di provinsi dengan laju pertumbuhan sektor yang sama di tingkat nasional. Analisis DLQ dapat digunakan untuk mengetahui reposisi sektor dari sektor basis menjadi sektor non basis atau sebaliknya. Analisis ini menekankan pada laju pertumbuhan sektoral. Nilai DLQ yang lebih besar dari 1 menunjukkan bahwa sektor/sub sektor pertanian memiliki kesempatan menjadi basis di masa mendatang. Artinya, laju pertumbuhan sektor/sub sektor pertanian di provinsi lebih cepat dibandingkan laju pertumbuhan sektor yang sama di nasional. Apabila nilai DLQ kurang dari 1 maka menunjukkan bahwa sektor/sub sektor pertanian tidak dapat diharapkan menjadi sektor basis di waktu yang akan datang. Artinya, laju pertumbuhan sektor/sub sektor pertanian di provinsi lebih lambat dibandingkan laju pertumbuhan sektor yang sama di nasional. Hasil analisis DLQ untuk sektor/sub sektor pertanian di Provinsi Jawa Barat dapat dilihat pada tabel 1.7.
Nilai DLQ didapatkan dari laju pertumbuhan PDRB sektor pertanian Provinsi Jawa Barat dibandingkan dengan laju pertumbuhan sektor yang sama di tingkat nasional. Berdasarkan hasil perhitungan DLQ, sektor pertanian Provinsi Jawa Barat memiliki nilai DLQ sebesar 0,965. Hal ini menunjukkan bahwa laju pertumbuhan PDRB sektor pertanian di tingkat Provinsi Jawa Barat lebih lambat dibandingkan laju pertumbuhan PDB sektor pertanian nasional. Sektor pertanian belum berpotensi menjadi sektor basis di Provinsi Jawa Barat untuk masa yang akan datang.

Hasil analisis DLQ sub sektor pertanian Provinsi Jawa Barat menunjukkan bahwa sub sektor tanaman bahan makanan dan hortikultura mengalami reposisi dari subsektor basis menjadi sub sektor basis. Hal ini menandakan bahwa sub sektor tanaman bahan makanan dan hortikultura tidak dapat diharapkan menjadi sub sektor basis di masa mendatang. Nilai DLQ untuk sub sektor tanaman bahan makanan dan hortikultura, perkebunan, peternakan, dan perikanan adalah $<1$, hal tersebut menandakan laju pertumbuhan PDRB keempat sub sektor di Provinsi Jawa Barat lebih lambat 
Tabel 1.9. Hasil Analisis Shift Share Sektor/Sub Sektor Pertanian Provinsi Jawa Barat Tahun 2003-2012 (milyar rupiah)

\begin{tabular}{lrrrr}
\hline \multirow{2}{*}{ Sektor/Sub Sektor } & \multicolumn{4}{c}{ Komponen } \\
\cline { 2 - 5 } & $\mathrm{N}_{\mathrm{ij}}$ & \multicolumn{1}{c}{$\mathrm{M}_{\mathrm{ij}}$} & \multicolumn{1}{c}{$\mathrm{C}_{\mathrm{ij}}$} & \multicolumn{1}{c}{$\mathrm{D}_{\mathrm{ij}}$} \\
\hline Pertanian & $21.172,41$ & $-9.541,08$ & $-1.907,95$ & $9.723,38$ \\
Tanaman Bahan Makanan & $15.638,93$ & $-7.778,90$ & $-378,66$ & $7.481,37$ \\
dan Hortikultura & & & & \\
Perkebunan & $1.218,20$ & $-594,79$ & $-108,97$ & 514,44 \\
Peternakan & $2.964,63$ & $-1.304,84$ & $-543,91$ & $1.115,89$ \\
Kehutanan & 176,62 & $-173,37$ & 89,37 & 92,63 \\
Perikanan & $1.174,03$ & 7,57 & $-662,55$ & 519,06 \\
\hline
\end{tabular}

Sumber: Analisis Data Sekunder, 2014.

apabila dibandingkan dengan laju pertumbuhan PDB sub sektor yang sama di tingkat nasional pada periode 2003-2012. Sementara itu, sub sektor kehutanan memiliki nilai DLQ $>1$ yang berarti laju pertumbuhan PDRB sub sektor kehutanan di Provinsi Jawa Barat lebih cepat dibandingkan laju pertumbuhan PDB sub sektor yang sama di tingkat nasional. Sub sektor kehutanan juga dapat diharapkan menjadi sub sektor basis dalam persaingan di masa mendatang.

Hasil analisis gabungan antara nilai LQ dan DLQ dapat dijadikan kriteria dalam menentukan klasifikasi sektor/sub sektor pada sektor/sub sektor pertanian. Klasifikasi sektor/sub sektor pertanian menghasilkan empat golongan, yaitu unggulan, prospektif, andalan, dan kurang prospektif (Kuncoro,2012).

Provinsi Jawa Barat tidak memiliki sektor/sub sektor yang tergolong dalam klasifikasi unggulan. Sektor pertanian, sub sektor perkebunan, sub sektor peternakan, dan sub sektor perikanan merupakan sektor/sub sektor tertinggal. Hal ini mengindikasikan bahwa sektor/sub sektor tersebut tidak berperan basis bagi Provinsi Jawa Barat. Sektor/sub sektor tersebut juga tidak memiliki potensi untuk menjadi basis di masa mendatang. Sektor pertanian, sub sektor perkebunan, peternakan, dan perikanan diprioritaskan untuk memenuhi kebutuhan akan sektor/sub sektor tersebut di wilayah Jawa Barat.

Sub sektor tanaman bahan makanan dan hortikultura merupakan sub sektor prospektif di Provinsi Jawa Barat. Sub sektor ini memiliki peran basis selama tahun 2003-2012 namun ke depannya sub sektor ini tidak memiliki potensi untuk tetap menjadi sub sektor basis. Hal ini dikarenakan laju pertumbuhan sub sektor tanaman bahan makanan dan hortikultura di provinsi lebih lambat dibandingkan dengan tingkat nasonal. Sub sektor andalan memerlukan upaya dalam hal kinerja sub sektor tersebut agar mengalami peningkatan menjadi sub sektor unggulan. Apabila tidak ada upaya dalam peningkatan kinerja, maka pada periode selanjutnya ada kemungkinan sub sektor ini mengalami penurunan peran menjadi non basis.

Sub sektor kehutanan tergolong dalam sub sektor andalan di Provinsi Jawa Barat, artinya sub sektor kehutanan memiliki peran non basis namun ke depannya memiliki potensi untuk menjadi sub sektor basis. Potensi yang terdapat pada sumber daya hutan produksi tetap dapat dimanfaatkan dengan optimal untuk meningkatkan produksi hasil hutan tanpa harus menambah luas hutan karena luas kawasan hutan produksi di Provinsi Jawa Barat tetap setiap tahunnya.

\section{Faktor yang Mempengaruhi Pertumbuhan Sektor Pertanian}

Analisis Shift Share digunakan untuk mengetahui kinerja komoditas pertanian di Provinsi Jawa Barat dan kabupaten/kota yang ada di Provinsi Jawa Barat. Pembahasan mengenai kinerja sektor/sub sektor pertanian menunjukkan bahwa perubahan PDRB kabupaten/kota selama periode analisis (2003-2012) dipengaruhi oleh komponen pertumbuhan daerah provinsi dan nasional $\left(\mathrm{N}_{\mathrm{ij}}\right)$, bauran industri $\left(\mathrm{M}_{\mathrm{ij}}\right)$ dan keunggulan kompetitif $\left(\mathrm{C}_{\mathrm{ij}}\right)$. Pengaruh-pengaruh tersebut pada provinsi dan masing-masing kabupaten/kota dapat dilihat pada tabel 1.9. 
Berdasarkan hasil analisis Shift Share sektor/sub sektor pertanian di Provinsi Jawa Barat, dampak riil pertumbuhan ekonomi provinsi bernilai positif untuk masing-masing sektor/sub sektor pertanian Provinsi Jawa Barat. Artinya pertumbuhan riil sektor pertanian mengalami peningkatan di seluruh sub sektor pertanian. Selama kurun waktu 2003-2012, Provinsi Jawa Barat mengalami kenaikan kinerja perekonomian pada sektor pertanian sebesar Rp 9,72 triliun. Kenaikan kinerja sektor pertanian didukung dengan kenaikan kinerja semua sub sektornya. Kinerja sub sektor pertanian terbesar dihasilkan oleh sub sektor tanaman bahan makanan dan hortikultura yaitu sebesar Rp 7,48 triliun.

Pertumbuhan ekonomi sektor/sub sektor pertanian nasional berpengaruh terhadap pertumbuhan sektor/sub sektor pertanian Provinsi Jawa Barat. Hal ini terlihat dari nilai $\mathrm{N}_{\mathrm{ij}}$ masingmasing sektor/sub sektor yang positif. Besaran pengaruh pertumbuhan ekonomi nasional terhadap sektor pertanian adalah Rp 21,17 triliun. Hal tersebut juga terjadi pada sub sektor tanaman bahan makanan dan hortikultura dengan nilai $\mathrm{N}_{\mathrm{ij}}$ sebesar Rp 15,64 triliun.

Sektor pertanian tidak menjadi spesialisasi Provinsi Jawa Barat dalam pendapatan daerah. Hal tersebut ditunjukkan dengan nilai bauran industrii yang negatif. Apabila dilihat secara parsial, pengaruh bauran industri $\left(\mathrm{M}_{\mathrm{ij}}\right)$ dari masingmasing sektor/sub sektor menunjukkan apabila hanya sub sektor perikanan yang dapat tumbuh dengan baik di tingkat provinsi. Artinya kegiatan ekonomi pada sektor pertanian di Provinsi Jawa Barat terkonsentrasi pada sub sektor perikanan.
Pertumbuhan sub sektor perikanan di nasional lebih cepat dibandingan pertumbuhan ekonomi total di nasional. Hal ini didukung dengan peran sub sektor perikanan sebagai sub sektor non basis di Provinsi Jawa Barat, artinya kontribusi dan laju pertumbuhan sub sektor perikanan di nasional lebih baik daripada di provinsi.

Berdasarkan nilai Competitive Shift $\left(\mathrm{C}_{\mathrm{ij}}\right)$, sub sektor kehutanan merupakan sub sektor yang memiliki keunggulan kompetitif atau daya saing yang lebih tinggi dibandingkan sub sektor yang sama di daerah lain di tingkat nasional. Laju pertumbuhan sub sektor kehutanan di provinsi lebih cepat dibandingkan dengan laju pertumbuhan di nasional. Sesuai dengan hasil analisis DLQ, pada waktu yang akan datang sub sektor kehutanan dapat menjadi basis dan memiliki daya saing dibandingkan dengan rata-rata nasional. Daya saing sub sektor kehutanan didukung oleh kondisi sumber daya alam di wilayah serta kebijakan pemerintah.

\section{Tipologi Pertumbuhan Sektor Pertanian di Provinsi Jawa Barat}

Analisis Tipologi Klassen untuk sektor dan sub sektor pertanian dilakukan pada tingkat kabupaten/kota dan provinsi. Hasil perhitungan dari analisis Tipologi Klassen dapat memberikan informasi yang selanjutnya dapat digunakan sebagai pedoman dalam perencanaan pembangunan ekonomi dan penentuan sektor prioritas dalam program pembangunan khususnya pada sektor/sub sektor pertanian di masing-masing kabupaten/kota dan Provinsi Jawa Barat. Hasil analisis Tipologi Klassen sektor/sub sektor pertanian Provinsi Jawa Barat dapat dilihat pada tabel 5.10.

Tabel 1.10. Klasifikasi Sektor/Sub Sektor Pertanian di Provinsi Jawa Barat Menurut Typologi Klassen

Tahun 2003-2012

\begin{tabular}{ccc}
\hline Laju Pertumbuhan Sektoral & \multicolumn{2}{c}{ Kontribusi Sektoral $(\mathrm{y})$} \\
\cline { 2 - 3 }$(\mathrm{r})$ & $\mathrm{y}_{\mathrm{j}}>\mathrm{y}_{\mathrm{n}}$ & $\mathrm{y}_{\mathrm{j}}<\mathrm{y}_{\mathrm{n}}$ \\
\hline $\mathrm{r}_{\mathrm{j}}>\mathrm{r}_{\mathrm{n}}$ & - & Kehutanan \\
& $($ Sektor Maju $)$ & $($ Sektor Berkembang $)$ \\
\hline $\mathrm{r}_{\mathrm{j}}<\mathrm{r}_{\mathrm{n}}$ & Tabama & Pertanian \\
& Peternakan & Perkebunan \\
& & Perikanan \\
& (Sektor Maju tapi Tertekan) & (Sektor Relatif Tertinggal) \\
\hline
\end{tabular}

Sumber: Analisis Data Sekunder, 2014. 
Hasil analisis Tipologi Klassen berhubungan dengan analisis LQ dan DLQ serta Shift Share. Klasifikasi sektor yang diperoleh dari hasil analisis LQ dan DLQ serta melihat hasil analisis Shift Share (pengaruh bauran industri dan keunggulan kompetitif) maka dapat mendukung atau memperkuat hasil klasifikasi dari analisis Tipologi Klassen. Apabila hasil analisis LQ dan DLQ menyatakan suatu sektor tertentu tergolong unggulan, serta sektor tersebut memiliki pengaruh bauran industri dan keunggulan kompetitif yang positif, artinya dapat menambah pertumbuhan PDRB maka sektor tersebut tergolong dalam sektor maju.

Berdasarkan klasifikasi Tipologi Klassen, sektor pertanian Provinsi Jawa Barat diklasifikasikan menjadi tiga kategori, yaitu sektor berkembang, maju tapi tertekan dan relatif tertinggal. Secara keseluruhan Provinsi Jawa Barat tidak memiliki sektor/sub sektor yang termasuk pada kategori sektor maju dan tumbuh cepat. Sub sektor tanaman bahan makanan dan sub sektor peternakan termasuk dalam kategori sektor maju tapi tertekan. Sub sektor yang masuk dalam kategori ini merupakan sub sektor yang relatif maju, kontribusinya terhadap nilai tambah provinsi relatif besar dibandingkan kontribusi sub sektor yang sama terhadap nilai tambah nasional namun pertumbuhannya pada beberapa tahun terakhir cenderung menurun. Sedangkan sektor pertanian, sub sektor perkebunan dan sub sektor perikanan termasuk dalam kategori sektor relatif tertinggal. Perlu ada tindakan dari pemerintah berupa kebijakan dalam pengelolaannya untuk mengembangkan ketiga sektor ini agar dapat menjadi sektor/sub sektor yang potensial untuk dikembangkan di Provinsi Jawa Barat. Sektor yang potensial bagi daerahnya diharapkan dapat memberikan nilai tambah yang besar sehingga berdampak positif bagi pertumbuhan sektor tersebut. Keadaan posisi sektor di provinsi dapat tercermin dari keadaan sektor/sub sektor di kabupaten/kota.

\section{KESIMPULAN}

1. PDRB sektor/sub sektor pertanian di Provinsi Jawa Barat memiliki kecenderungan meningkat dan kontribusi PDRB sektor/sub sektor pertanian di Provinsi Jawa Barat memiliki kecenderungan menurun yang signifikan selama tahun 2003-2012.

2. Sektor pertanian merupakan sektor non basis bagi Provinsi Jawa Barat dan sebagian besar kabupaten/kota di Provinsi Jawa Barat. Sub sektor tanaman bahan makanan dan hortikultura merupakan sub sektor basis bagi Provinsi Jawa Barat dan sebagian kecil kabupaten/kota di Provinsi Jawa Barat.

3. Pertumbuhan ekonomi nasional merupakan faktor dominan yang berpengaruh terhadap pertumbuhan sektor/sub sektor pertanian di Provinsi Jawa Barat. Sub sektor kehutanan memiliki keunggulan kompetitif (daya saing) yang lebih tinggi dibandingkan sub sektor yang sama di daerah lain di tingkat nasional.

4. Sub sektor tanaman bahan makanan dan hortikultura dan sub sektor peternakan termasuk dalam sub sektor maju tapi tertekan. Sub sektor kehutanan termasuk dalam kategori sub sektor berkembang. Sedangkan sektor pertanian, sub sektor perkebunan dan sub sektor perikanan sebagai sektor/sub sektor yang relatif tertinggal.

\section{DAFTAR PUSTAKA}

Arsyad, L. 2010. Ekonomi Pembangunan. STIM YKPN, Yogyakarta.

Gujarati, D.N. 2006. Dasar-dasar Ekonometrika. Penerbit Erlangga, Jakarta.

Kuncoro, M. 2012. Perencanaan Daerah: Bagaimana Membangun Ekonomi Lokal, Kota dan Kawasan?. Penerbit Salemba Empat, Jakarta.

Nazir, M. 2011. Metode Penelitian. Penerbit Ghalia Indonesia, Bogor.

Nugroho, A.D. 2010. Komoditas unggulan tanaman pangan di Pulau Jawa. Jurnal Agro Ekonomi Vol. 17 No.1 : 67-72.

Widodo, T. 2006. Perencanaan Pembangunan: Aplikasi Komputer (Era Otonomi Daerah). UPP STIM YKPN, Yogyakarta. 